\title{
Perencanaan Perkerasan Kaku Jalan Eksisting Lenangguar - Lunyuk STA 04 - STA 06
}

\author{
Ummi Khairiyah Br Maha ${ }^{\mathrm{a}^{*}}$, Hermansyah ${ }^{\mathrm{a}}$, Dedy Dharmawansyah ${ }^{\mathrm{a}}$ \\ ${ }^{\text {a }}$ Program Studi Teknik Sipil, Fakultas Teknik, Universitas Teknologi Sumbawa, Nusa Tenggara Barat, 84371, Indonesia
}

Keywords:

Rigid pavement design

Lunyuk

\begin{abstract}
The existence of roads is essential to support economic growth, agriculture, and other sectors. This is because the road is an essential means of transportation to serve people and goods from one place to another safely, comfortable, and economical. Therefore, it is necessary to plan related to the road pavement. Inappropriate pavement planning is the main cause of road damage. The planning for rigid pavement refers to the often-used guidelines, namely, the Road Pavement Design Manual (Revised on June 2017). The thick design of rigid pavement for the Lenangguar - Lunyuk, using quality of concrete of $K_{400}$ with a thickness of $19 \mathrm{~cm}$. The subfoundation uses Lean Mix Concrete with $K_{125}$ concrete quality and $10 \mathrm{~cm}$ of thickness. Dowel $33 \mathrm{~mm}$ in diameter uses steel bars $45 \mathrm{~cm}$ in length and $40 \mathrm{~cm}$ distances. Tie Bar fastener with $16 \mathrm{~mm}$ in diameter using a threaded rod, length $70 \mathrm{~cm}$, and distance between rods $75 \mathrm{~cm}$, respectively.
\end{abstract}

\section{ABSTRAK}

Keberadaan jalan raya sangatlah penting untuk menunjang laju pertumbuhan ekonomi, pertanian dan sektor lainnya. Hal ini dikarenakan jalan merupakan suatu sarana transportasi yang sangat penting untuk melayani pergerakan manusia dan atau barang dari suatu tempat ke tempat lain secara aman, nyaman dan ekonomis, maka dari itu perlu dilakukan perencanaan terkait perkerasan jalan. Perencanaan perkerasan jalan yang tidak sesuai menjadi penyebab utama dari kerusakan jalan. Perencanaan pekerasan kaku ini mengacu pada pedoman yang sering digunakan yaitu, Manual Desain Perkerasan Jalan (Revisi Juni 2017). Dalam rancangan tebal perkerasan kaku jalan lintas Lenangguar - Lunyuk, menggunakan beton K 400 dengan tebal $19 \mathrm{~cm}$. Pondasi bawah menggunakan Lean Mix Concrete dengan mutu beton K 125 dengan tebal $10 \mathrm{~cm}$. Dowel berdiameter $33 \mathrm{~mm}$ menggunakan ruji baja polos degan panjang 45 $\mathrm{cm}$ dan jarak $40 \mathrm{~cm}$. Pengikat Tie Bar berdiameter $16 \mathrm{~mm}$ menggunakan batang ulir, panjang $70 \mathrm{~cm}$ dan jarak antar batang $75 \mathrm{~cm}$.

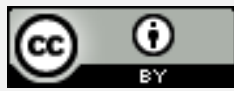

This is an open access article under the CC-BY license.

\section{Pendahuluan}

Jalan lintas Lenangguar - Lunyuk merupakan jalan yang menghubungkan Desa Lenangguar dan Desa Lunyuk yang masuk dalam kategori jalan provinsi. Jalan Lenangguar - Lunyuk terletak di wilayah selatan dan sebagian besar terdiri dari dataran tinggi dengan ketinggian rata-rata 231 meter dari permukaan laut.

Jenis perkerasan pada jalan Lintas Lenangguar - Lunyuk saat ini menggunakan perkerasan lentur (Aspal). Perkerasan ini memiliki beberapa keunggulan diantaranya adalah memiliki nilai ekonomis tinggi, akan tetapi memiliki kelemahan terhadap kondisi cuaca. Sehingga inovasi terus dilakukan untuk perbaikan sifat fisik dan mekaniknya sebagaimana yang dilakukan oleh [1]-[4]. Banyaknya jenis kendaraan yang melintas pada ruas jalan ini menyebabkan kerusakan pada beberapa titik dibagian badan jalan. Kerusakan ini berupa, badan jalan yang tidak rata akibat penurunan tanah, lubang-lubang akibat genangan air hujan dan lain-lain. Pada tahun 2019 terjadi kerusakan pada badan jalan dikarenakan semakin meningkatnya jumlah kendaraan yang melintas [5]. Untuk meminimalisir terjadinya kerusakan jalan yang lebih 
serius lagi, maka dari itu perlu dilakukannya perencanaan terkait tebal perkerasan jalan yang sesuai dengan kondisi tanah dasar dari jalan tersebut dan mampu melayani beban kendaraan yang melintas pada arus jalan tersebut.

Perencanaan perkerasan jalan yang digunakan disini adalah perkerasan kaku. Pemilihan jenis perkerasan ini karena perkerasan kaku merupakan perkerasan jalan yang memiliki tingkat kekakuan yang cukup tinggi dibandingkan dengan perkerasan lentur (aspal) sebesar 10 kali lipat. Meskipun penelitian Penyebaran beban yang relatif luas pada daerah subgrade dan beton sendiri bagian utama yang menanggung beban struktural.

Perencanaan tebal perkerasan kaku ini mengacu pada metode Manual Perkerasan Jalan yang merupakan salah satu metode perencanaan perkerasan kaku yang umum digunakan [6] sampai dengan [7].

\section{Metode}

\subsection{Lokasi Penelitian}

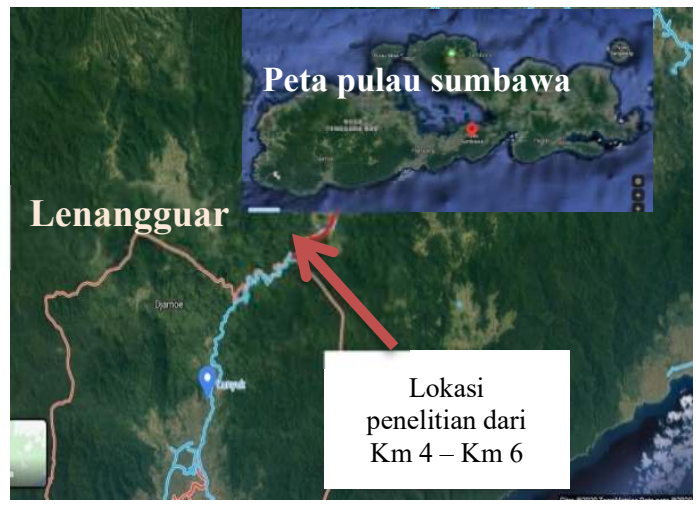

Gambar 1. Lokasi penelitian

\subsection{Jenis Penelitian}

Penelitian ini dilakukan dengan mengumpulkan data-data dari dinas terkait dan melakukan survey langsung ke lokasi penelitian. Perencanaan dilakukan agar uraian datadata yang diperoleh dapat mencakup seluruh permasalahan dalam penelitian. Data diperoleh dari data lalu lintas harian rerata dan data hujan simpang bersinyal seturunan.

\subsection{Tahapan Penelitian}

Desain perkerasan kaku memerlukan data-data mengenai obyek yang akan direncanakan. Data yang dibutuhkan dalam penelitian ini berupa data lalu lintas harian rerata (LHR) dan data hari hujan yang selanjutnya dihitung menggunakan metode Bina Marga tahun 2017. Tahapan penelitian yang digunakan dapat dijelaskan dalam bagan alir pada Gambar 2.

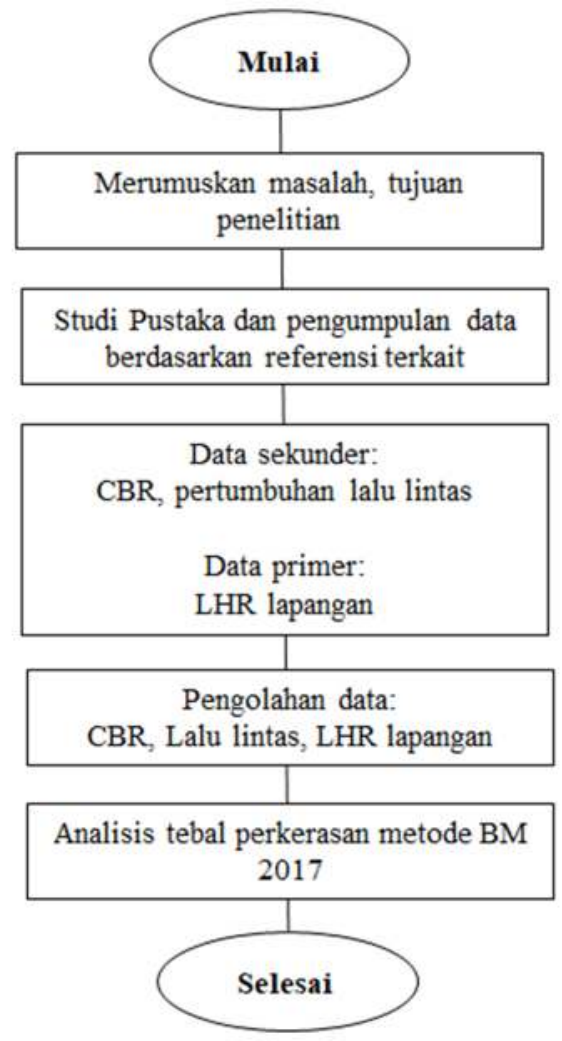

Gambar 2. Bagan alir penelitian

\subsection{Perencanaan dengan Menggunakan Metode Bina Marga 2017}

Metode ini mengacu pada pedoman Manual Desain Perkerasan Jalan [6] dan pedoman Manual Desain Perkerasan Jalan [8]. Sistem perhitungan tebal pelat beton perkerasan dengan metode Bina Marga tahun 2017.

\section{Hasil dan Pembahasan}

\subsection{Data Lalu Lintas}

Data lalu lintas yang digunakan yaitu data LHR (lalu lintas harian rata-rata) ini adalah data primer yang didapatkan melalui survey secara langsung ke lokasi penelitian. Survey ini dilakukan selama satu pekan kemudian menentukan hari puncak atau jadwal lalu lintas terpadat. 


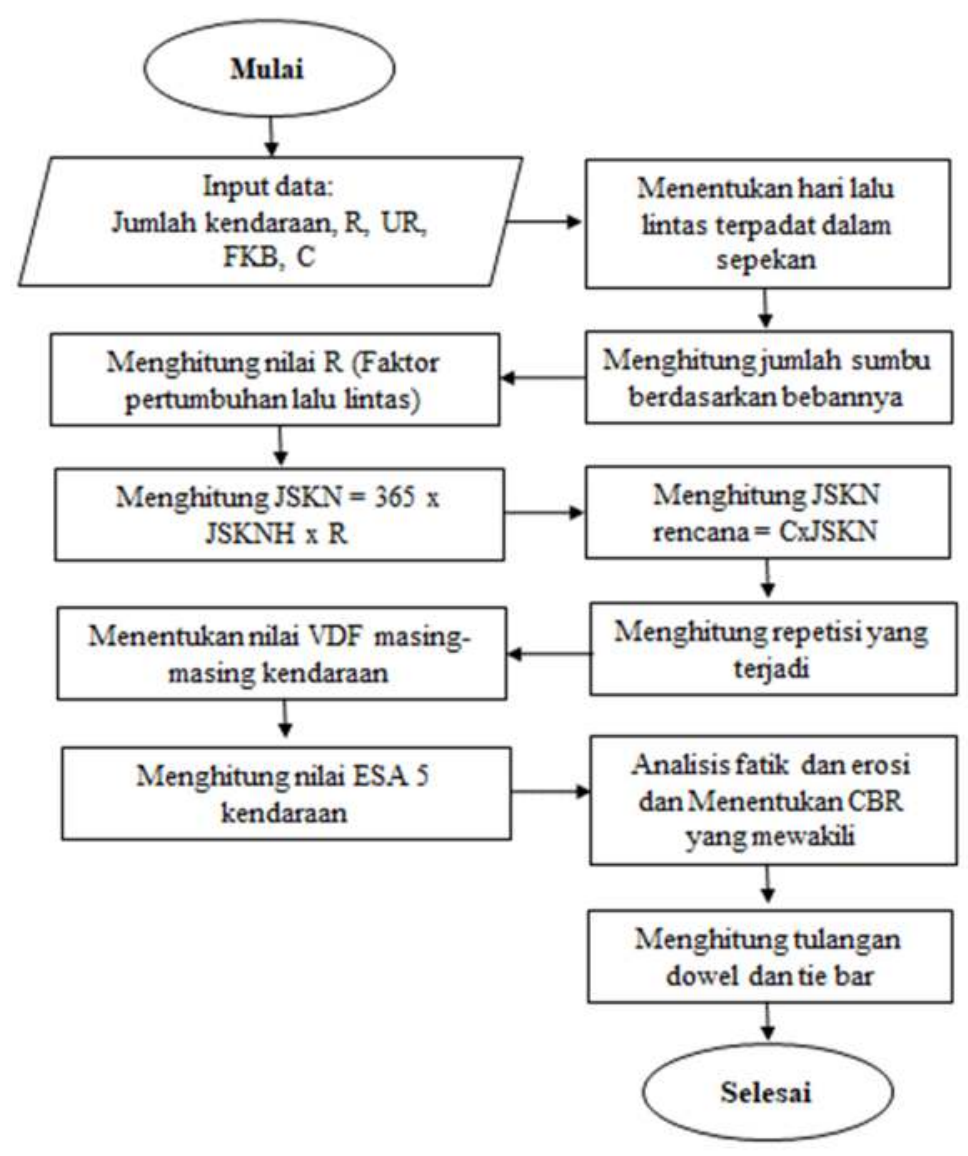

Gambar 3. Bagan alir perencanaan metode Bina Marga 2017[9]

\subsection{Analisa Data Pertumbuhan Lalu Lintas}

Dari hasil survey kendaraan selama satu pekan, maka ditentukan hari puncak banyaknya kendaraan yaitu hari selasa sebagai awal pekan, hari kammis sebagai pertengahan pekan dan hari sabtu sebagai akhir pekan. Adapun data LHR puncak yang didapatkan dapat dilihat pada Tabel 2.

Jumlah sumbu kendaraan niaga (JSKN) selama umur rencana 20 tahun.

$$
\begin{aligned}
\mathrm{R}= & \frac{(1+0,01 \times \mathrm{i})^{\mathrm{UR}}-1}{0,01 \times \mathrm{i}} \\
= & \frac{(1+0,01 \times 3,5)^{20}-1}{0,01 \times 3,5} \\
=28,28 & \\
\mathrm{JSKN} & =365 \times \mathrm{JSKNH} \times \mathrm{R} \\
& =365 \times 1258 \times 28,28 \\
& =1,2 \times 10^{7}
\end{aligned}
$$

\begin{tabular}{|c|c|c|c|c|c|c|c|c|c|c|c|c|c|}
\hline \multirow{3}{*}{$\begin{array}{c}\text { Jenis Kend } \\
1\end{array}$} & \multicolumn{4}{|c|}{$\begin{array}{l}\text { Konsfigurasi beban Smb } \\
\text { (ton) }\end{array}$} & \multirow{2}{*}{$\begin{array}{c}\text { Jumlah } \\
\text { Kend } \\
\text { (bh) }\end{array}$} & \multirow{2}{*}{$\begin{array}{l}\text { Jumlah } \\
\text { Smb/ken }\end{array}$} & \multirow{2}{*}{$\begin{array}{l}\text { Jumlah } \\
\text { Smb }\end{array}$} & \multicolumn{2}{|c|}{ STRT } & \multicolumn{2}{|c|}{ STRG } & \multicolumn{2}{|c|}{ STdRG } \\
\hline & $\mathrm{RD}$ & $\begin{array}{l}\mathrm{R} \\
\mathrm{B}\end{array}$ & $\begin{array}{l}\text { RG } \\
\mathrm{D}\end{array}$ & RGB & & & & $\begin{array}{l}\text { BS } \\
\text { (bh) }\end{array}$ & $\begin{array}{l}\text { JS } \\
\text { (bh) }\end{array}$ & $\begin{array}{l}\text { BS } \\
\text { (bh) }\end{array}$ & $\begin{array}{l}\text { JS } \\
\text { (bh) }\end{array}$ & $\begin{array}{l}\text { BS } \\
\text { (bh) }\end{array}$ & $\begin{array}{l}\text { JS } \\
\text { (bh) }\end{array}$ \\
\hline & & & 2 & & 3 & 4 & $5=3 \times 4$ & 6 & 7 & 8 & 9 & 10 & 11 \\
\hline Motor & 1 & 1 & & & 3851 & & & & & & & & \\
\hline Pick Up & 1 & 1 & & & 629 & & & & & & & & \\
\hline Mobil Box & 1 & 1 & & & 113 & & & & & & & & \\
\hline Bus Kecil & 3 & 5 & & & 14 & 2 & 28 & 3 & 14 & 5 & 14 & & \\
\hline Bus Sedang & 3 & 5 & & & 19 & 2 & 38 & 3 & 19 & 5 & 19 & & \\
\hline Truck Kecil & 2 & 4 & & & 247 & 2 & 294 & $\begin{array}{l}2 \\
4\end{array}$ & $\begin{array}{l}247 \\
247\end{array}$ & & & & \\
\hline Truk Sedang & 5 & 8 & & & 243 & 2 & 686 & 5 & 243 & 8 & 243 & & \\
\hline
\end{tabular}

JSKN Rencana $=\mathrm{C} \times \mathrm{JSKN}$

$$
\begin{aligned}
& =1.00 \times 1.2 \times 10^{7} \\
& =1.2 \times 10^{7}
\end{aligned}
$$

Tabel 1. Jumlah sumbu berdasarkan bebannya 


\begin{tabular}{|c|c|c|c|c|c|c|c|c|c|c|c|c|c|}
\hline \multirow{3}{*}{$\begin{array}{c}\text { Jenis Kend } \\
1 \\
\end{array}$} & \multicolumn{4}{|c|}{$\begin{array}{l}\text { Konsfigurasi beban Smb } \\
\text { (ton) }\end{array}$} & \multirow{2}{*}{$\begin{array}{l}\text { Jumlah } \\
\text { Kend } \\
\text { (bh) }\end{array}$} & \multirow{2}{*}{$\begin{array}{l}\text { Jumlah } \\
\text { Smb/ken }\end{array}$} & \multirow{2}{*}{$\begin{array}{l}\text { Jumlah } \\
\text { Smb }\end{array}$} & \multicolumn{2}{|c|}{ STRT } & \multicolumn{2}{|c|}{ STRG } & \multicolumn{2}{|c|}{ STdRG } \\
\hline & $\mathrm{RD}$ & $\begin{array}{l}\mathrm{R} \\
\mathrm{B}\end{array}$ & $\begin{array}{c}\mathrm{RG} \\
\mathrm{D}\end{array}$ & RGB & & & & $\begin{array}{l}\text { BS } \\
\text { (bh) }\end{array}$ & $\begin{array}{c}\mathrm{JS} \\
\text { (bh) }\end{array}$ & $\begin{array}{l}\text { BS } \\
\text { (bh) }\end{array}$ & $\begin{array}{c}\mathrm{JS} \\
(\mathrm{bh})\end{array}$ & $\begin{array}{l}\text { BS } \\
\text { (bh) }\end{array}$ & $\begin{array}{c}\mathrm{JS} \\
\text { (bh) }\end{array}$ \\
\hline & & & 2 & & 3 & 4 & $5=3 \times 4$ & 6 & 7 & 8 & 9 & 10 & 11 \\
\hline \multirow[t]{2}{*}{ Truck 3 Gandar } & 6 & 14 & & & 6 & 2 & 12 & 6 & 6 & & & 14 & 6 \\
\hline & \multicolumn{4}{|c|}{ Total } & & & 1258 & & 776 & & 276 & 14 & 6 \\
\hline
\end{tabular}

Tabel 2. Data lalu lintas terpadat satu pekan

\begin{tabular}{|c|c|c|c|c|c|c|c|c|}
\hline \multirow[b]{2}{*}{ Waktu } & \multicolumn{8}{|c|}{ Jenis Kendaraan } \\
\hline & Motor & Pick Up & $\begin{array}{c}\text { Mobil } \\
\text { Box }\end{array}$ & $\begin{array}{c}\text { Bus } \\
\text { Besar }\end{array}$ & Bus Kecil & $\begin{array}{l}\text { Truck } \\
\text { Kecil }\end{array}$ & $\begin{array}{c}\text { Truck } \\
\text { Sedang }\end{array}$ & $\begin{array}{l}\text { Truck } 3 \\
\text { Gandar }\end{array}$ \\
\hline Selasa, 01 Sep 2020 & 1694 & 178 & 20 & 4 & 7 & 80 & 77 & 4 \\
\hline Kamis, 03 Sep 2020 & 749 & 246 & 44 & 5 & 6 & 78 & 79 & \\
\hline Sabtu, 05 Sep 2020 & 676 & 180 & 49 & 6 & 8 & 89 & 89 & 2 \\
\hline Total & 3119 & 604 & 113 & 15 & 21 & 247 & 245 & 6 \\
\hline
\end{tabular}

Selanjutnya, setelah didapatkan jumlah sumbu niaga maka akan dilakukan perhitungan repetisi sumbu yang terjadi, perhitungan repetisi sumbu yang terjadi dapat dilihat pada Tabel 3 yang terdiri dari jenis sumbu, beban sumbu, jumlah sumbu, proporsi beban dan sumbu, lalu lintas rencana sampai dengan repetisi beban yang terjadi pada obyek penelitian.

\subsection{Data Nilai CBR subgrade (Tanah Dasar)}

Data rangkuman tes CBR Timbunan Pilihan adalah data skunder yang di dapatkan dari Dinas PUPR (Pekerjaan Umum dan Penataan Ruang) Provinsi Nusa Tenggara Barat. Nilai CBR tanah dasar yang mewakili dari sejumlah harga CBR yang dilaporkan diketahui sebagai berikut: 12.65:12.51:10.47 disajikan pada Tabel 6.

Tabel 3. Perhitungan repetisi yang terjadi

\begin{tabular}{|c|c|c|c|c|c|c|c|}
\hline Jenis Sumbu & $\begin{array}{l}\text { Beban } \\
\text { Sumbu }\end{array}$ & \multicolumn{2}{|l|}{$\begin{array}{l}\text { Jumlah } \\
\text { Sumbu }\end{array}$} & $\begin{array}{l}\text { Proporsi } \\
\text { Beban }\end{array}$ & $\begin{array}{l}\text { Proporsi } \\
\text { Sumbu }\end{array}$ & $\begin{array}{l}\text { Lalu Lintas } \\
\text { Rencana }\end{array}$ & $\begin{array}{c}\text { Repetisi yang } \\
\text { Terjadi }\end{array}$ \\
\hline 1 & 2 & \multicolumn{2}{|l|}{3} & 4 & 5 & 6 & $7=4 \times 5 \times 6$ \\
\hline \multirow{5}{*}{ STRT } & 6 & \multicolumn{2}{|l|}{6} & 0.01 & 0.73 & $1.2 \times 10^{7}$ & $8.6 \times 10^{4}$ \\
\hline & 5 & \multicolumn{2}{|l|}{243} & 0.31 & 0.73 & $1.2 \times 10^{7}$ & $2.7 \times 10^{6}$ \\
\hline & 4 & \multicolumn{2}{|l|}{247} & 0.32 & 0.73 & $1.2 \times 10^{7}$ & $2.8 \times 10^{6}$ \\
\hline & 3 & \multicolumn{2}{|l|}{33} & 0.04 & 0.73 & $1.2 \times 10^{7}$ & $3.5 \times 10^{5}$ \\
\hline & 2 & \multicolumn{2}{|l|}{247} & 0.32 & 0.73 & $1.2 \times 10^{7}$ & $2.8 \times 10^{6}$ \\
\hline Total & & \multicolumn{2}{|l|}{776} & 1 & & & \\
\hline \multirow{2}{*}{ STRG } & 8 & \multicolumn{2}{|l|}{243} & 0.88 & 0.26 & $1.2 \times 10^{7}$ & $2.7 \times 10^{6}$ \\
\hline & 5 & \multicolumn{2}{|l|}{33} & 0.12 & 0.26 & $1.2 \times 10^{7}$ & $3.7 \times 10^{5}$ \\
\hline Total & & \multicolumn{2}{|l|}{276} & 1 & & & \\
\hline STdRG & 14 & \multicolumn{2}{|l|}{6} & 1 & 0.01 & $1.2 \times 10^{7}$ & $1.2 \times 10^{5}$ \\
\hline Total & & \multirow{2}{*}{\multicolumn{2}{|c|}{$\begin{array}{c}6 \\
1058 \\
\end{array}$}} & 1 & & & \\
\hline Kumulatif & & & & & & & $11.9 \times 10^{6}$ \\
\hline \multicolumn{8}{|c|}{ Tabel 5. Perhitungan ESA 5} \\
\hline \multirow{2}{*}{ Jenis kendaraan } & LHRT & LHRT & LHRT & VDF 5 & VDF 5 & ESA 5 & ESA 5 \\
\hline & 2020 & 2023 & 2026 & Aktual & Normal & $(22 "-25 ”)$ & $(23 "-40 ")$ \\
\hline 1 & 2 & 3 & 4 & 5 & 6 & 7 & 8 \\
\hline $\begin{array}{l}\text { MP\& kendaraan } \\
\text { ringan }\end{array}$ & 4593 & 5291 & 6095 & & & & \\
\hline $5 \mathrm{~A}$ & 14 & 16 & 18 & 1,0 & 1,0 & $9.081,20$ & $74.062,35$ \\
\hline $5 b$ & 19 & 22 & 25 & 1,0 & 1,0 & $12.486,65$ & $103.614,38$ \\
\hline $6 \mathrm{a} 1$ & 247 & 284 & 303 & 0,5 & 0,5 & $80.595,65$ & $627.903,11$ \\
\hline $6 \mathrm{~b} 1.1$ & 243 & 280 & 299 & 4,0 & 3,0 & $63.556,84$ & $3.717 .683,78$ \\
\hline $7 \mathrm{a} 2$ & 6 & 8 & 11 & 9,7 & 6,0 & $44.043,82$ & $273.541,95$ \\
\hline & & & & & & $78.1892,32$ & $4.796 .805,56$ \\
\hline & & Total & & & & & $5.578 .696,88$ \\
\hline
\end{tabular}


Keterangan:

Kolom : $3=2 \times(1+i)^{\text {n }}$

Kolom : $4=2 \times(1+i)^{n}$
Kolom : $7=(3) \times(5) \times 365 \times 0.5 \times 1 \times R_{(2022-2025)}$

Kolom : $8=(4) \times(6) \times 365 \times 0.5 \times 1 \times R_{(2023-2040)}$

Tabel 6. Data nilai CBR [10]

\begin{tabular}{cccc}
\hline No & CBR & Jumlah yang sama atau lebih besar & Persen\% yang sama atau lebih besar \\
\hline 1 & 10.47 & 3 & $3 / 3 \times 100 \%=100 \%$ \\
2 & 12.51 & 2 & $2 / 3.100 \%=66.6 \%$ \\
3 & 12.65 & 1 & $1 / 3.100 \%=33.3 \%$ \\
\hline
\end{tabular}

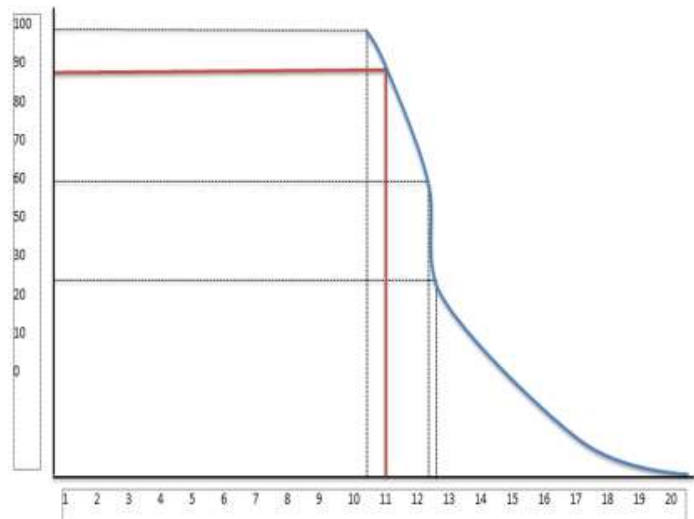

Gambar 4. Nilai CBR lapangan

\subsection{Data Perencanaan Tebal Perkerasan Kaku (Rigid Pavement)}

Data pendukung lainnya yang berhubungan dengan penentuan tebal perkerasan kaku (rigid pavement) mengacu kepada [8]-[13]: (a) Umur rencana yang ditentukan untuk perencanaan tebal perkerasan kaku (rigid pavement) yaitu 20 tahun; (b) Fungsi jalan yaitu arteri atau jalan bebas hambatan (freeway) menghubungkan antar kota atau antar daerah yang menghendaki waktu dan jarak tempuh dengan efektif; (c) Panjang jalan yang direncanakan $\mathrm{km} 4 \mathrm{~s} / \mathrm{d} \mathrm{km} 6$ (3 Km); (d) Terdiri dari 1 lajur 2 arah dengan tanpa menggunakan bahu jalan; (e) Faktor keamanan beban FKB jalan Kolektor 1,00; (f) Kuat tarik lentur beton (f'cf) $4 \mathrm{MPa}$ (F'c = $285 \mathrm{~kg} / \mathrm{cm}^{2}$ silinder); (g) Nilai CBR tanah dasar $11 \%$; (8) Pertumbuhan lalu lintas (i) 3,50\% pertahun diambil dari nilai pertumbuhan lalu lintas rata-rata seluruh Indonesia; (h) Tebal pelat yang ditaksir $19 \mathrm{~cm}$; (i) Material yang digunakan dalam perkerasan kaku (rigid pavement) yaitu: (a) Subbase menggunakan lean-mix concrete dengan beton mutu K125 $10 \mathrm{~cm}$; (b) Perkerasan kaku (rigid pavement) dengan tipe Beton Bersambung Tanpa Tulangan (BBTT) dengan Ruji menggunakan mutu beton $\mathrm{K}_{400}$.

Setelah data perencanaan tebal pelat ditentukan, maka selanjutnya yang dilakukan adalah menganalisis nilai fatik dan erosi yang akan terjadi. Untuk mengetahui tegangan ekivalen dan faktor erosi selanjutnya dapat dilihat pada Gambar 4. Karena nilai CBR sebesar 11\% tidak terdapat pada tabel, maka digunakan nilai CBR sebesar $10 \%$.

Tabel 7. Tegangan ekivalen dan faktor erosi [14]

\begin{tabular}{|c|c|c|c|c|c|c|c|c|c|c|c|c|c|}
\hline \multirow{3}{*}{$\begin{array}{c}\text { Tebal } \\
\text { slab } \\
(\mathrm{mm})\end{array}$} & \multirow{3}{*}{$\begin{array}{l}\text { CBR } \\
\text { eff tnh } \\
\text { dsr(\%) }\end{array}$} & \multirow{2}{*}{\multicolumn{4}{|c|}{ Tegangan Setara }} & \multicolumn{8}{|c|}{ Faktor erosi } \\
\hline & & & & & & & & a Ruji & & & Deng & Ruji & \\
\hline & & STRT & STRG & STdRG & $\begin{array}{l}\mathrm{STr} \\
\mathrm{RG}\end{array}$ & STRT & STRG & STdRG & STrRG & STRT & $\begin{array}{c}\text { STR } \\
\mathrm{G} \\
\end{array}$ & $\begin{array}{c}\text { STd } \\
\text { RG } \\
\end{array}$ & $\begin{array}{l}\mathrm{STr} \\
\mathrm{RG}\end{array}$ \\
\hline 190 & 5 & 0,99 & 1,58 & 1,35 & 1,05 & 2,07 & 2,67 & 2,78 & 2,82 & 1,86 & 2,46 & 2,57 & 2,64 \\
\hline 190 & 10 & 0,96 & 1,49 & 1,26 & 0,99 & 2,05 & 2,65 & 2,72 & 2,75 & 1,84 & 2,44 & 2,51 & 2,56 \\
\hline 190 & 15 & 0,94 & 1,44 & 1,21 & 0,97 & 2,04 & 2,64 & 2,70 & 2,72 & 1,83 & 2,43 & 2,48 & 2,53 \\
\hline 190 & 20 & 0,93 & 1,42 & 1,19 & 0,96 & 2,03 & 2,63 & 2,69 & 2,70 & 1,82 & 2,42 & 2,46 & 2,50 \\
\hline 190 & 25 & 0,92 & 1,40 & 1,17 & 0,94 & 2,03 & 2,63 & 2,67 & 2,68 & 1,81 & 2,41 & 2,44 & 2,48 \\
\hline 190 & 35 & 0,90 & 1,35 & 1,12 & 0,91 & 2,02 & 2,62 & 2,63 & 2,64 & 1,79 & 2,40 & 2,40 & 2,43 \\
\hline 190 & 50 & 0,88 & 1,29 & 1,08 & 0,88 & 2,00 & 2,60 & 2,60 & 2,60 & 1,77 & 2,38 & 2,36 & 2,38 \\
\hline 190 & 75 & 0,87 & 1,22 & 1,02 & 0,86 & 1,98 & 2,58 & 2,55 & 2,55 & 1,76 & 2,36 & 2,32 & 2,38 \\
\hline 200 & 5 & 0,91 & 1,47 & 1,27 & 0,99 & 2,01 & 2,61 & 2,74 & 2,78 & 1,8 & 2,4 & 2,52 & 2,6 \\
\hline 200 & 10 & 0,89 & 1,39 & 1,18 & 0,93 & 1,99 & 2,59 & 2,69 & 2,71 & 1,78 & 2,38 & 2,46 & 2,52 \\
\hline 200 & 15 & 0,87 & 1,35 & 1,15 & 0,9 & 1,98 & 2,59 & 2,66 & 2,68 & 1,77 & 2,37 & 2,43 & 2,49 \\
\hline 200 & 20 & 0,86 & 1,33 & 1,12 & 0,89 & 1,97 & 2,58 & 2,64 & 2,66 & 1,76 & 2,36 & 2,42 & 2,48 \\
\hline 200 & 25 & 0,85 & 1,3 & 1,1 & 0,87 & 1,97 & 2,57 & 2,62 & 2,64 & 1,75 & 2,35 & 2,4 & 2,44 \\
\hline 200 & 35 & 0,83 & 1,25 & 1,05 & 0,84 & 1,96 & 2,56 & 2,58 & 2,6 & 1,73 & 2,33 & 2,36 & 2,39 \\
\hline 200 & 50 & 0,82 & 1,2 & 1,01 & 0,82 & 1,94 & 2,54 & 2,55 & 2,55 & 1,71 & 2,31 & 2,32 & 2,33 \\
\hline 200 & 75 & 0,81 & 1,14 & 0,95 & 0,8 & 1,92 & 2,52 & 2,51 & 2,5 & 1,69 & 2,3 & 2,27 & 2,26 \\
\hline
\end{tabular}


Tabel 8. Analisa fatik dan erosi

\begin{tabular}{|c|c|c|c|c|c|c|c|c|}
\hline \multirow[b]{2}{*}{$\begin{array}{c}\text { Jenis } \\
\text { Sumbu }\end{array}$} & \multirow{2}{*}{$\begin{array}{c}\text { Beban } \\
\text { Sumbu } \\
\text { Ton } \\
(\mathrm{KN})\end{array}$} & \multirow{2}{*}{$\begin{array}{c}\text { Beban } \\
\text { Rencana } \\
\text { Per Roda } \\
(\mathrm{kn})\end{array}$} & \multirow[b]{2}{*}{$\begin{array}{c}\text { Repetisi } \\
\text { yang Terjadi }\end{array}$} & \multirow[b]{2}{*}{$\begin{array}{c}\text { Faktor Tegangan } \\
\text { dan Erosi }\end{array}$} & \multicolumn{2}{|c|}{ Analisa Fatik } & \multicolumn{2}{|c|}{ Analisa Erosi } \\
\hline & & & & & $\begin{array}{c}\text { Repetisi } \\
\text { Ijin }\end{array}$ & Persen Rusak & $\begin{array}{c}\text { Repetisi } \\
\text { Ijin }\end{array}$ & $\begin{array}{l}\text { Persen } \\
\text { Rusak }\end{array}$ \\
\hline 1 & 2 & 3 & 4 & 5 & 6 & $7=4 \times 100 / 6$ & 8 & $9=4 \times 100 / 8$ \\
\hline STRT & $\begin{array}{l}6(60) \\
5(50) \\
4(40) \\
3(30) \\
2(20) \\
\end{array}$ & $\begin{array}{l}30,00 \\
25,00 \\
20,00 \\
15,00 \\
10,00 \\
\end{array}$ & $\begin{array}{l}8,6 \times 10^{4} \\
2,7 \times 10^{6} \\
2,8 \times 10^{6} \\
3,5 \times 10^{5} \\
2,8 \times 10^{6} \\
\end{array}$ & $\begin{array}{c}\mathrm{TE}=0,96 \\
\mathrm{FRT}=0,26 \\
\mathrm{FE}=1,84\end{array}$ & $\begin{array}{l}\text { TT } \\
\text { TT } \\
\text { TT } \\
\text { TT } \\
\text { TT } \\
\end{array}$ & $\begin{array}{l}0 \\
0 \\
0 \\
0 \\
0 \\
\end{array}$ & $\begin{array}{l}\text { TT } \\
\text { TT } \\
\text { TT } \\
\text { TT } \\
\text { TT } \\
\end{array}$ & $\begin{array}{l}0 \\
0 \\
0 \\
0 \\
0\end{array}$ \\
\hline STRG & $\begin{array}{l}8(80) \\
5(50)\end{array}$ & $\begin{array}{l}20,00 \\
12,50\end{array}$ & $\begin{array}{l}2,7 \times 10^{6} \\
3,7 \times 10^{5}\end{array}$ & $\begin{array}{c}\mathrm{TE}=1,49 \\
\mathrm{FRT}=0,41 \\
\mathrm{FE}=2,44\end{array}$ & $\begin{array}{l}\text { TT } \\
\text { TT }\end{array}$ & $\begin{array}{l}0 \\
0\end{array}$ & $\begin{array}{l}\text { TT } \\
\text { TT }\end{array}$ & $\begin{array}{l}0 \\
0\end{array}$ \\
\hline STdRG & $14(140)$ & 17,50 & $1,2 \times 10^{5}$ & $\begin{array}{c}\mathrm{TE}=1,26 \\
\mathrm{FRT}=0,34 \\
\mathrm{FE}=2,51\end{array}$ & $\mathrm{TT}$ & 0 & $\mathrm{TT}$ & 0 \\
\hline \multicolumn{5}{|c|}{ Total } & \multicolumn{2}{|r|}{0} & \multicolumn{2}{|c|}{$0<100 \%$} \\
\hline
\end{tabular}

Karena nilai \% rusak fatik yang didapat lebih kecil 100\% maka tebal pelat yang direncanakan setebal $190 \mathrm{~mm}$ (19 $\mathrm{cm})$ dapat digunakan.

\subsection{Perhitungan Dowel dan Tulangan}

\subsubsection{Dowel}

Untuk menentukan ukuran dowel sebagai pengikat/penyambung pada sambungan pelat beton dengan tebal pelat perkerasan sebesar $190 \mathrm{~mm}(19 \mathrm{~cm})$, direncanakan ruji yang digunakan adalah ruji baja polos. Pada saat pemasangan dowel sebagai penyambung/ pengikat separuh panjang terikat dan separuh dilumasi atau dicat untuk memberikan kebebasan bergerak pada pelat beton dan tidak salinng terikat. Diameter dowel yang digunakan dapat dilihat pada Tabel 11, dan didapatkan ukuran dowel sebagai berikut:

$\begin{array}{ll}\text { Diameter } & =33 \mathrm{~mm} \\ \text { Panjang } & =450 \mathrm{~mm} \\ \text { Jarak anatar ruji } & =300 \mathrm{~mm}\end{array}$

\subsubsection{Pengikat Tie Bar}

Disarankan untuk sambungan memanjang harus dilengkapi dengan batang ulir. Batang ulir yang bergerigi akan memperkuat/mepererat sambungan batang dengan pelat beton, sehingga akan menambah kekuatan pada pelat beton. Batang ulir yang digunakan dengan mutu minimum BJTU- 24 dan berdiameter $16 \mathrm{~mm}$. Untuk ukuran batang pengikat tie bar dapat ditentukan dengan persamaan dibawah ini:

$$
\begin{aligned}
\mathrm{I} & =(38,3 \times \phi)+75 \\
& =(38,3 \times 16)+75
\end{aligned}
$$

$$
\begin{aligned}
& =687,8 \mathrm{~mm} \\
& =700 \mathrm{~mm} \\
& =70 \mathrm{~cm}
\end{aligned}
$$

Jadi, dowel dan pengikat tie bar yang digunakan adalah sebagai berikut:

Jenis perkerasan $=$ Perkerasan Beton bersambung

Tanpa Tulangan dengan ruji

Tebal pelat $\quad=190 \mathrm{~mm}=19 \mathrm{~cm}$

Lebar pelat $\quad=2 \times 2,5 \mathrm{~m}$

Panjang pelat $=5 \mathrm{~m}$

Sambungan susut setiap jarak $\quad=5 \mathrm{~m}$

Ruji digunakan dengan diameter $\quad=33 \mathrm{~mm}$

Panjang ruji $\quad=450 \mathrm{~mm}$

Jarak ruji $\quad=300 \mathrm{~mm}$

Batang pengikat digunakan baja ulir :

$\begin{array}{ll}\text { Diameter } & =16 \mathrm{~mm} \\ \text { Panjang } & =70 \mathrm{~cm} \\ \text { Jarak } & =75 \mathrm{~cm}\end{array}$

\section{Simpulan}

Dari penelitian tersebut, didapatkan hasil perencanaan perkerasan jalan yang sesuai dengan Metode Manual Desain Perkerasan Jalan tahun 2017 yaitu : (a) Rancangan tebal perkerasan kaku (Rigid Pavement) ini menggunakan jenis perkerasan beton semen bersambung tanpa tulangan (BBTT) dengan ruji. Beton yang digunakan untuk struktur atas adalah $\mathrm{K}_{400}$ dengan ketebalan $19 \mathrm{~cm}$, didapatkan dari perhitungan tebal perkerasan. Pondasi bawah beton menggunakan lean-mix concrete dengan beton mutu $\mathrm{K}$ $12510 \mathrm{~cm}$. Dowel yang digunakan berdiameter $33 \mathrm{~mm}$, panjang $45 \mathrm{~cm}$, jarak $40 \mathrm{~cm}$ dan jarak setiap sambungan dowel adalah $4 \mathrm{~m}$ didapatkan dari hasil perhitungan dowel; (b) Sambungan pada dowel menggunakan baja polos. 


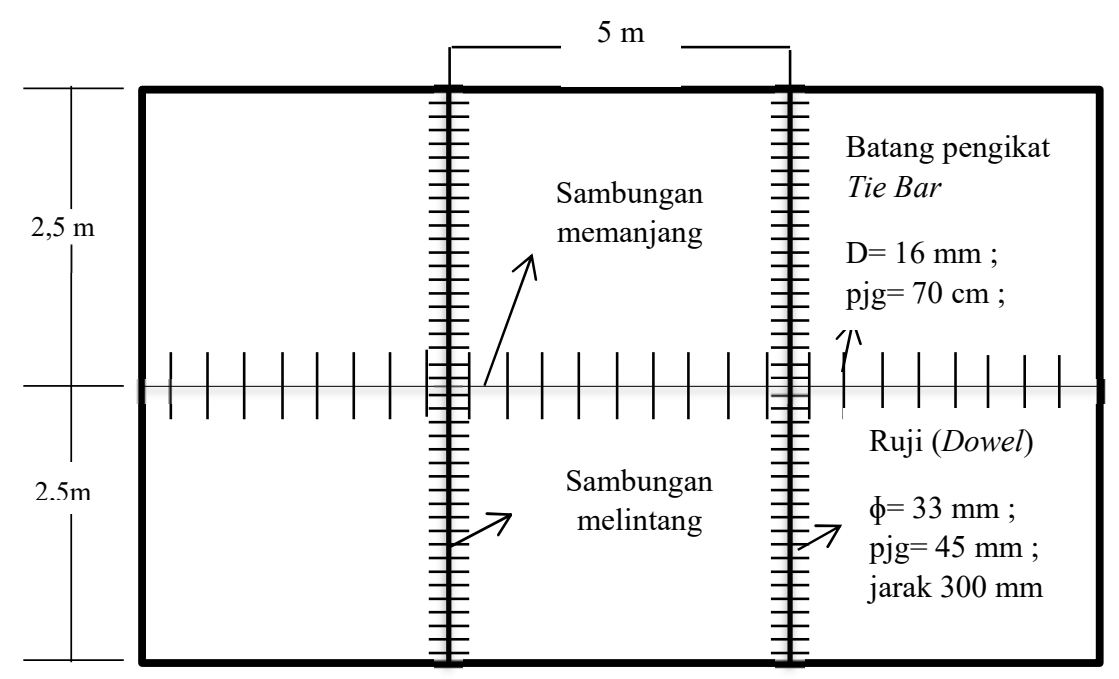

Gambar 5. Perkerasan Beton Bersambung Tanpa Tulangan (BBTT)

Pengikat tie bar berdiameter $16 \mathrm{~mm}$, panjang $70 \mathrm{~cm}$ dan jarak antar batang $75 \mathrm{~cm}$ didapatkan dari hasil perhitungan umur rencana 20 tahun.

\section{Daftar Rujukan}

[1] F. Ma'arif, "Efek variasi kadar bitumen terhadap kinerja Marshall laboratorium dengan menggunakan agregat Bantak (studi kinerja agregat Bantak dengan menggunakan emulsi, modifikasi polymer, AC 60/70 dan Shell (Singapore) pada lalulintas berat)," INERSIA, vol. 2, no. 8, 2012, doi: https://doi.org/10.21831/inersia.v8i2.3999.

[2] S. Sukirman, Beton Aspal Campuran Panas. Jakarta: Granit, 2003.

[3] F. Ma'arif and Pramudiyanto, "Uji kinerja Marshall agregat Bantak Merapi dengan menggunakan serat polypropylene," INERSIA, vol. 10, no. 1, 2014, doi: https://doi.org/10.21831/inersia.v10i1.4424.

[4] H. Hardiyatmo, Pemeliharaan Jalan Raya. Yogyakarta: Gajah Mada University Press, 2007.

[5] BPS Kabupaten Sumbawa, "Kecamatan Lenangguar dalam Angka 2018," Sumbawa, 2018.

[6] Kementerian Pekerjaan Umum dan Perumahan Rakyat Direktorat Jendral Bina Marga, Perkerasan Jalan (Revisi Juni 2017) Nomor 04/SE/Db/2017. Jakarta: Kementrian Pekerjaan Umum Perumahan Rakyat, 2017.
[7] Kementrian Pekerjaan Umum Direktorat Jendral Bina Marga, Manual Desain Perkerasan Jalan, Nomor 02/M/BM/2013. Jakarta: Kementrian Pekerjaan Umum, 2013.

[8] Departemen Permukiman dan Prasarana Wilayah, Perencanaan Tebal Perkerasan Jalan Semen Beton Metode SNI 2003 Pd T-14-2003. Jakarta: Departemen Permukiman dan Prasarana Wilayah, 2003.

[9] Direktorat Jendral Bina Marga, Manual Kapasitas Jalan Indonesia (MKJI). Jakarta: Departemen Pekerjaan Umum, 1997.

[10] H. C. Hardiyatmo, Analisis dan Perancanagn Fondasi 2, Cetakan Pertama. Yogyakarta: Gajah Mada Press, 2015.

[11] I. Hadijah and M. Harizalsyah, "Perencanaan Jalan Dengan Perkerasan Kaku Menggunakan Metode Analisa Komponen Bina Marga," Universitas Muhammaddiyah Metro, 2017.

[12] A. Suryawan, Perkerasan Jalan Beton Semen Portland (Rigid Pavement) : Seri Buku Teknik Sipil Praktis. Yogyakarta: Beta Offset, 2016.

[13] A. Suryawan, Perkerasan Jalan Beton Semen Portland(Rigid Pavement). Yogyakarta: Beta Offset, 2009.

[14] S. Totomihardjo, Bahan dan Struktur Jalan Raya. Yogyakarta: Biro Penerbit KMTS FT UGM, 2004. 